\title{
Development and Validation of a P-35S, T-nos, T-35S and P-FMV Tetraplex Real- time PCR Screening Method to Detect Regulatory Genes of Genetically Modified Organisms in Food
}

\author{
Albert Eugster*, Petra Murmann, Andre Kaenzig, and Alda Breitenmoser
}

\begin{abstract}
In routine analysis screening methods based on real-time PCR (polymerase chain reaction) are most commonly used for the detection of genetically modified (GM) plant material in food and feed. Screening tests are based on sequences frequently used for GM development, allowing the detection of a large number of GMOs (genetically modified organisms). Here, we describe the development and validation of a tetraplex real-time PCR screening assay comprising detection systems for the regulatory genes Cauliflower Mosaic Virus 35S promoter, Agrobacterium tumefaciens nos terminator, Cauliflower Mosaic Virus 35S terminator and Figwort Mosaic Virus $34 \mathrm{~S}$ promoter. Three of the four primer and probe combinations have already been published elsewhere, whereas primers and probe for the $35 \mathrm{~S}$ terminator have been developed in-house. Adjustment of primer and probe concentrations revealed a high PCR sensitivity with insignificant physical cross-talk between the four detection channels. The sensitivity of each PCR-system is sufficient to detect a GMO concentration as low as $0.05 \%$ of the containing respective element. The specificity of the described tetraplex is high when tested on DNA from GM maize, soy, rapeseed and tomato. We also demonstrate the robustness of the system by inter-laboratory tests. In conclusion, this method provides a sensitive and reliable screening procedure for the detection of the most frequently used regulatory elements present in GM crops either authorised or unauthorised for food.
\end{abstract}

Keywords: GMO detection · P-35S · P-FMV · Screening · T-35S · Tetraplex real-time PCR $\cdot$ T-nos

\section{Introduction}

Every year an increasing number of different genetically modified (GM) plants are grown on commercial scale. This growing number of different genetically modified crops comes along with an increase in the diversity of genetic modifications in commercialised GMOs. Therefore, broad and sensitive testing methods are needed. In Europe, the routine analysis of food, feed and seeds are mostly based on PCR screening methods for the detection of authorised and not authorised GMO crops because DNA is more resistant to food processing than proteins. Real-time PCR has become state of the art in routine analysis because of the reduced risk of sample contamination and the possibility to quantify the analyte, at least in a semiquantitative manner. Among the currently proposed real-

\footnotetext{
${ }^{\star}$ Correspondence: A. Eugster

Cantonal Office of Consumer Protection Aargau Aarau

Tel. : +4162 8353020

E-mail: albert.eugster@ag.ch
}

time PCR chemistry, Taqman ${ }^{\mathrm{TM}}$ seems to represent the most appropriate system regarding muliplexing capacities, ease of primer and probe design, as well as cost considerations.

PCR tests are generally divided in four categories: screening, construct-specific, event-specific and taxa reference systems for quantification. Screening tests are based on common sequences frequently used for GMO development such as promoters, terminators and genes of interest like cry encoding insecticidal proteins from Bacillus thuringiensis or sequences of genes conferring tolerances to herbicides or antibiotics.

In routine analysis most laboratories prefer to carry out initial screening PCRs targeting regulatory DNA elements such as the 35S Promoter of Cauliflower Mosaic virus or the nos terminator of Agrobacterium tumefaciens. In order to detect these two genes, singleplex real-time PCR systems were published. ${ }^{[1,2]}$ The invention of multiplex real-time PCR systems was a remarkable step forward in terms of saving costs, time and template DNA of samples with very low content of DNA. ${ }^{[3-9]}$ A critical aspect linked to multiplex real-time PCR assays is the increased possibility of cross- talk, which is an increase of fluorescence in a detection channel caused by a dye, that is not intended to be measured in the given detection channel. Hence, it is of particular importance to optimise the combination of reporter dyes in a multiplex assay.

This article describes the development and validation of a sensitive tetraplex real-time PCR for the simultaneous detection and semiquantitative estimation of the P-35S and T-nos which is extended for the detection of T-35S and P-FMV sequence, two regulatory elements often incorporated in GM plants. Positive screening results have to be verified using construct- and/or event-specific methods.

\section{Materials and Methods}

\section{Materials}

During the development of this method, the following reference materials have been used: Roundup Ready ${ }^{\mathrm{TM}}$ soya flour (RRS or GTS 40-3-2) from IRMM (Geel, Belgium) was purchased from Sigma-Aldrich, Buchs, Switzerland; T25 maize kernels were a gift from the Federal Food Safety and Veterinary Office, Bern, Switzerland; GT73 rapeseed kernels were 
a gift from the State Institute for Chemical and Veterinary Analysis of Food, Freiburg i. B., Germany.

To test the specificity, additional reference materials were used: A2704-12 soybean leaf DNA and A5547-127 soybean leaf DNA from AOCS, Urbana, USA; MON810 and GA21 (Roundup Ready) maize kernels were a gift from Federal Food Safety and Veterinary Office, Bern, Switzerland; Bt11 maize flour with 2 w/w\% GMO content from IRMM (Geel, Belgium) was purchased from SigmaAldrich, Buchs, Switzerland; Oxy235 rapeseed DNA with $1 \%$ gmo content purchased from Sigma-Aldrich, Buchs, Switzerland; FlavrSavr ${ }^{\mathrm{TM}}$ (CGN-89564-2) tomato was a gift from the State Institute for Chemical and Veterinary Analysis of Food, Freiburg i. B., Germany.

The following samples from GeMMA scheme proficiency tests (FAPAS, Sand Hutton, England) were used: GeM21 snack crumbs, GeMC12 A to C wheat flours, GeMC07 baked products, GeMC03 mixed flour, GeMD07 rice DNA.

Eight samples on general sale based on corn, soy and rice were used for a proficiency test of the Swiss GMO working group.

\section{DNA Extraction and Quantification}

All samples were extracted with a modified Wizard $^{\mathrm{TM}}$ procedure (Promega, Wisconsin, USA) according to Swiss Food Manual..10]

Briefly, $300 \mathrm{mg}$ of sample material was weighed, $860 \mu \mathrm{L}$ extraction buffer $(10 \mathrm{mM}$
Tris- $\mathrm{HCl}, \mathrm{pH} 8.0,150 \mathrm{mM} \mathrm{NaCl}, 2 \mathrm{mM}$ EDTA, $1 \%$ SDS), $100 \mu \mathrm{L}$ guanidinium-hydrochloride $(5 \mathrm{~mol} / \mathrm{l})$ and $40 \mu \mathrm{L}$ proteinase $\mathrm{K}(20 \mathrm{mg} / \mathrm{mL})$ were added. The mixture was shaken at $60{ }^{\circ} \mathrm{C}$ for at least $3 \mathrm{~h}$. After cooling the samples were centrifuged for $10 \mathrm{~min}$ at $12^{\prime} 000 \times$ g. $5 \mu \mathrm{L}$ RNase $(10 \mathrm{mg}$ / $\mathrm{ml})$ were added to $500 \mu \mathrm{L}$ of the supernatant. After $10 \mathrm{~min}$ at $60{ }^{\circ} \mathrm{C}$ (hydrolysis of the RNA), 1 mL Wizard ${ }^{\circledR}$-Resin was added and mixed by gentle inversion. Further processing of the samples was done according to the recommendations of the manufacturer. Finally, the DNA was eluted with $50 \mu \mathrm{L}$ hot $\left(70{ }^{\circ} \mathrm{C}\right)$ elution buffer $(10$ $\mathrm{mM}$ Tris- $\mathrm{HCl}, \mathrm{pH}$ 9.0). DNA concentrations were measured at $260 \mathrm{~nm}$ using the NanoDrop (ND-2000 Spectrophotometer, Saveen Werner, USA) and adjusted to 20 $\mathrm{ng} / \mu \mathrm{L}$ with water.

The DNA extracted from FAPAS GeMMA scheme proficiency tests for example showed an OD ratio $(260 / 280 \mathrm{~nm})$ of 1.68-1.82, indicating a sufficient DNA quality.

\section{Design of Primers and Probes}

The primers and probe combination for the $35 \mathrm{~S}$ promoter ${ }^{11]}$ and for the nos terminator[11] have already been published. The sequences for the primers and probe for the FMV 34S promoter were a gift from a commercial service laboratory, ${ }^{[12]}$ whereas primers and probe for $35 \mathrm{~S}$ terminator have been developed in-house. The sequences of all the primers and probes are summarised in Table 1.

The primers and probes were synthesised by Microsynth AG, Balgach, Switzerland.

\section{Real-time PCR Procedure}

Sample extracts $(5 \mu \mathrm{L}, 20 \mathrm{ng} / \mu \mathrm{L}$ DNA) were added to $20 \mu \mathrm{l}$ of reaction mix containing 2× QuantiTect multiplex PCR no ROX Master Mix (Qiagen, Hilden, Germany), converting all primers and probes to a final concentration described in Table 1. A PCR was performed on a Rotorgene 6000 real-time PCR cycler (Qiagen, Hilden, Germany) according to the following cycling protocol: Initial denaturation (15 min at $\left.95^{\circ} \mathrm{C}\right)$, cycle denaturation $(15 \mathrm{sec}$ at 95 ${ }^{\circ} \mathrm{C}$ ), primer annealing, elongation and data collection $\left(1 \mathrm{~min}\right.$ at $\left.60^{\circ} \mathrm{C}\right) ; 45$ cycles.

\section{Results and Discussion}

\section{Optimisation of the Tetraplex System}

One of the primary goals of the optimisation of multiplex real-time PCR assays was to achieve a good sensitivity, via a high PCR efficiency for all target sequences, comparable to those of the singleplex PCR reactions. Optimisation was performed by variation of primer concentrations from 0.1 to $0.5 \mu \mathrm{M}$ with a relatively low template concentration of approximately $0.1 \%$ GMO content of the respective element. Starting with one optimised singleplex system, the next singleplex system is then added and the construct was tested again. The aim was to maintain the performance characteristics, mainly the sensitivity, the shape of the amplification curves and the reproducibility of each implemented single system. The performance of the tetraplex PCR system corresponds to the performance of the single PCR systems.

Table 1. Sequences of primers and probes.

\begin{tabular}{|c|c|c|}
\hline $\begin{array}{l}\text { Primer/ } \\
\text { Probe }\end{array}$ & $\begin{array}{l}\text { Final } \\
\text { conc. } \\
{[\mu \mathrm{M}]}\end{array}$ & Sequence $5^{\prime}-3^{\prime}$ \\
\hline P-35S-F & 0.2 & GCC TCT GCC GAC AGT GGT \\
\hline P-35S-R & 0.2 & AAG ACG TGG TTG GAA CGT CTT C \\
\hline P-35S-FAM & 0.1 & FAM-CAA AGA TGG ACC CCC ACC CAC G-TAMRA \\
\hline T-nos-F & 0.3 & ACA TGC TTA ACG TAA TTC AAC AG \\
\hline T-nos-R & 0.3 & TCA AAC ATT TGG CAA TAA AGT TTC \\
\hline T-nos-ROX & 0.1 & ROX-AAT CCT GTT GCC GGT CTT GCG AT-BHQ2 \\
\hline $\mathrm{T}-35 \mathrm{~S}-\mathrm{F}$ & 0.3 & GTG AGT AGT TCC CAG ATA AG \\
\hline T-35S-R & 0.3 & GGG TTT CTT ATA TGC TCA AC \\
\hline T-35S-JOE & 0.1 & Joe-ATT AGG GTT CYT ATA GGG TTT CGC TCA T-BHQ1 \\
\hline P-FMV-F & 0.2 & AGG CGC ACC TAC CAA AAG C \\
\hline P-FMV-R & 0.2 & CGT TAT TTT GTT CCC CAC TTG TAC T \\
\hline P-FMV-Cy5 & 0.1 & $\begin{array}{l}\text { Cy5-TCT TTG CCT TTA TTG CAA AGA TAA AGC AGA } \\
\text { TTC C-BHQ2 }\end{array}$ \\
\hline
\end{tabular}

\begin{tabular}{|l|l|l|l|l|}
$\begin{array}{l}\text { Ampli- } \\
\text { con }\end{array}$ & $\begin{array}{l}\text { Exci- } \\
\text { tation } \\
{[\mathrm{bp}]}\end{array}$ & $\begin{array}{l}\text { Emis- } \\
\text { sion } \\
{[\mathrm{nm}]}\end{array}$ & Colour & Ref. \\
\hline 83 & & & & \\
\hline
\end{tabular}

95

73

82

$585 \quad 610 \quad$ orange

this

work

\begin{tabular}{l|l|l}
530 & $555 \quad$ yellow
\end{tabular}

\begin{tabular}{l|l}
625 & $660 \quad$ red
\end{tabular}

FAM: 6-carboxylfluorescein, ROX: carboxyl-X-rhodamine, JOE: 6-carboxy-4',5'-dichloro-2',7'-dimethoxyfluorescein, Cy5: 'cyanine dye', TAMRA: 6-carboxytetramethylrhodamine, BHQ: black hole quencher. The column 'Final conc.' indicates the concentration in $\mu \mathrm{M}$ of a primer or probe in the PCR reaction. The column 'Amplicon' represents the PCR amplicon size in base pairs. 


\section{Sensitivity}

To evaluate the sensitivity, three different reference materials were used: Roundup Ready $^{\mathrm{TM}}$ soya flour (GTS 40-3-2); T25 maize kernels, and GT73 rapeseed kernels. After isolating the DNA, the Roundup Ready ${ }^{\mathrm{TM}}$ soya DNA with $0.1 \%$ GMO content was diluted twice with water to a GMO content of $0.05 \%$. DNA from T25 maize kernels and GT73 rapeseed kernels were diluted stepwise to a final GMO concentration of $0.05 \%$ with herring sperm DNA of $20 \mathrm{ng} / \mu \mathrm{L}$ concentration as background. The mean $\mathrm{Ct}$ values and their standard deviation obtained by measuring are summarised in Table 2. The corresponding copy numbers in the single PCR reactions of the used test samples with $0.05 \%$ GMO are 44 (soy, genome size $1.13 \mathrm{pg} / \mathrm{C}$ ), 19 (maize, genome size $2.7 \mathrm{pg} / \mathrm{C}$ ) and 43 (rapeseed, genome size $1.15 \mathrm{pg} / \mathrm{C}$ ) respectively. The relatively low $\mathrm{Ct}$ values as well as the low standard deviations indicate that the used reference materials could be detected in a reasonably low concentration. Further optimisation of the system for even lower concentrations can be omitted as samples with plant material often contain traces of naturally occurring donor organisms for these screening elements like cauliflower mosaic virus (P-35S) or soil bacteria (T-nos), which simulate GMO traces.

\section{Analysis of Samples from Proficiency Tests}

The results of the samples from FAPAS GeMMA scheme proficiency tests could also be interpreted as a form of sensitivity and specificity test of the present method (Table 3). One has to take into account that the content of the GMO plant species itself can be low. For example, in the sample GeM21 (snack crumbs) the total soy content is only $10 \%$. The adjoining screening

Table 2. List of the measured Ct values testing the sensitivity. The DNA of the GMO events maize T25 and rapeseed GT73 are produced with a background of $20 \mathrm{ng} / \mathrm{ml}$ herring testes DNA while the soybean RRS DNA contains soybean and soybean RRS DNA only. The PCR runs have been done with 5 replicates. The columns with the screening elements show the mean Ct values ' $\mathrm{Ct}$ ' and their standard deviation 'SD'.

\begin{tabular}{|l|l|l|l|l|l|l|l|l|l|l|}
\hline GMO event & $\begin{array}{l}\text { Amount of } \\
\text { GMO event }\end{array}$ & P-35S & & T-nos & & \multicolumn{2}{|c}{ T-35S } & \multicolumn{3}{c|}{ P-FMV } \\
\hline pg/reaction & Ct & SD & Ct & SD & Ct & SD & Ct & SD \\
\hline Soybean RRS & 50 & 31.8 & 0.33 & 29.9 & 0.39 & - & & - & \\
Maize T25 & 50 & 30.5 & 0.57 & - & & 33.0 & 0.43 & - & \\
Rapeseed GT73 & 50 & - & & - & & - & & 32.8 & 0.54
\end{tabular}

elements are in good accordance with the GM crop database of the American Center for Environmental Risk Assessment.[13]

\section{Specificity}

The specificity tests were conducted for the following reference materials: Roundup Ready ${ }^{\mathrm{TM}}$ soya flour with 5 w/w\% GMO content; A2704-12 soybean leaf DNA, A5547-127 soybean leaf DNA; T25 maize kernels; MON810 and GA21 (Roundup Ready) maize kernels; Bt11 maize flour with $2 \mathrm{w} / \mathrm{w} \%$ GMO content; Oxy235 rapeseed DNA with 1\% GMO; FlavrSavr ${ }^{\mathrm{TM}}$ tomato.

The $\mathrm{Ct}$ values obtained by measurement are summarised in Table 4 . The presence or absence of the detected screening elements are in good accordance with the GM crop database of the American Center for Environmental Risk Assessment. [13]

Furthermore, DNAs from conventional non-GMO plants were analysed in a concentration of $20 \mathrm{ng} / \mu \mathrm{L}$. No cross reactivity was observed with the following plant species: soy (Glycine max), maize (Zea mays), wheat (Triticum aestivum), rye (Secale cereale), oat (Avena sativa), rice (Oryza sati- va), rapeseed (Brassica napus), cauliflower (Brassica oleracea var. botrytis), red pepper (Capsicum annuum) and chestnut (Castanea sativa). The described real-time PCR method showed a very good specificity for the listed screening elements compared to other relevant plant species often used in food products.

\section{Analysis of Ring Trial Samples of the Swiss GMO Working Group}

Eight samples on general sale were analysed using the described method. Each sample was brought in by food authority labs and analysed for the presence of GMO in the last few years by routine analysis. The participants of the proficiency test have received a lyophilised mixture with all the primers and probes described in this method. The results are summarised in Table 5. On the whole, the participants obtained the expected results for each of the screening elements. Sample 2 with a concentration of $0.01 \%$ of each GMO event only, showed, nevertheless, many positive screening results. One has to consider that all participants of the proficiency test were free in their choice of DNA extraction method

Table 3. List of the measured Ct values testing materials from FAPAS GeMMA proficiency tests for the presence or absence of the detected screening elements. These $\mathrm{Ct}$ values give information concerning the sensitivity, specificity and the correct detection of the particular method. The noted Ct values represent the mean value of 3 replicates.

\begin{tabular}{|c|c|c|c|c|c|c|c|c|c|c|}
\hline Sample & Matrix & $\begin{array}{l}\text { GMO added } \\
{[\%]}\end{array}$ & $\begin{array}{l}\mathrm{P}-35 \mathrm{~S} \\
\text { added }\end{array}$ & $\begin{array}{l}\mathrm{P}-35 \mathrm{~S} \\
\mathrm{Ct}\end{array}$ & $\begin{array}{l}\text { T-nos } \\
\text { added }\end{array}$ & $\begin{array}{l}\text { T-nos } \\
\mathrm{Ct}\end{array}$ & $\begin{array}{l}\text { T-35S } \\
\text { added }\end{array}$ & $\begin{array}{l}\mathrm{T}-35 \mathrm{~S} \\
\mathrm{Ct}\end{array}$ & $\begin{array}{l}\text { P-FMV } \\
\text { added }\end{array}$ & $\begin{array}{l}\text { P-FMV } \\
\mathrm{Ct}\end{array}$ \\
\hline GeM21 & Snack food crumbs & $1.1 \% \mathrm{RRS}$ & yes & 27.6 & yes & 26.0 & no & - & no & - \\
\hline GeMC03 & Mixed flour & $\begin{array}{l}1.21 \% \text { RRS and } \\
1.15 \% \text { MON810 }\end{array}$ & yes & 26.6 & yes & 25.1 & no & - & no & - \\
\hline GeMC07 & Baked product & $1.71 \%$ MON810 & yes & 31.6 & no & $35.2^{\mathrm{a}}$ & no & - & no & - \\
\hline GeMC12A & Wheat flour & - & no & - & no & - & no & - & no & - \\
\hline GeMC12B & Wheat flour & Soy & no & - & no & - & no & - & no & - \\
\hline GeMC12C & Wheat flour & $7.3 \%$ MON810 & yes & 29.3 & no & - & & - & & - \\
\hline GeMD16A & DNA & $1.17 \%$ LLRice 62 & yes & 24.8 & no & - & yes & 26.5 & no & - \\
\hline
\end{tabular}

This sample has been identified by 25 of 45 participants of the ring trial containing traces of RRS as a contamination. 
Table 4. List of the measured Ct values from two replicates testing the specificity.

\begin{tabular}{|l|l|l|l|l|l|l|}
\hline GMO Event & $\begin{array}{l}\text { Conc. } \\
\text { GMO }\end{array}$ & $\begin{array}{l}\text { Conc. } \\
\text { DNA }\end{array}$ & P-35S & T-nos & T-35S & P-FMV \\
\hline Soybean RRS & 5 & 20 & $26.4 / 26.5$ & $23.5 / 23.5$ & - & Ct \\
\hline Soybean A2704-12 & 100 & 20 & $19.6 / 19.7$ & $33.5 / 35.5^{\mathrm{a}}$ & $20.4 / 20.4$ & - \\
Soybean A5547-127 & 100 & 20 & $21.9 / 21.8$ & - & $22.7 / 22.5$ & - \\
Maize T25 & 100 & 20 & $22.3 / 22.4$ & - & $23.3 / 23.3$ & - \\
Maize MON810 & 100 & 20 & $29.1 / 29.2$ & - & - & - \\
Maize Bt11 & 2 & 20 & $29.0 / 29.2$ & $26.4 / 26.2$ & $31.4 / 31.3^{\text {b }}$ & - \\
Maize GA21 & 5 & 20 & - & $23.2 / 23.3$ & - & - \\
Rapeseed GT73 & 100 & 10 & - & - & - & $26.4 / 26.1$ \\
Rapeseed Oxy235 & 1 & ca. 2 & 40.1 & $-{ }^{c}$ & - & - \\
Tomato Flavr Savr & 100 & $<1$ & $25.2 / 25.4$ & - & - & - \\
\hline
\end{tabular}

aSample is contaminated with RRS; ${ }^{\circ}$ The amplification curves of this sample are unusually flat as a consequence of unspecific amplification; 'Sample is too diluted to detect the T-nos element.

\begin{tabular}{|c|c|c|c|c|c|c|}
\hline Sample & Matrix & GMO event [\%] & $\begin{array}{l}\text { P-35S } \\
\text { Det exp } \\
+/-/ n c\end{array}$ & $\begin{array}{l}\text { T-nos } \\
\text { Det exp } \\
+/-/ n c\end{array}$ & $\begin{array}{l}\text { T-35S } \\
\text { Det exp } \\
+/-/ n c\end{array}$ & $\begin{array}{l}\text { P-FMV } \\
\text { Det exp } \\
+/-/ n c\end{array}$ \\
\hline 1 & corn & $\begin{array}{l}\text { MON810; } 0.01 \\
\text { NK603; } 0.05 \\
\text { TC1507; } 0.16 \\
\text { MON88017; } 0.01 \\
\text { MIR604; } 0.01\end{array}$ & $\begin{array}{l}\text { yes } \\
10 / 0 / 0\end{array}$ & $\begin{array}{l}\text { yes } \\
10 / 0 / 0\end{array}$ & $\begin{array}{l}\text { yes } \\
8 / 2 / 0\end{array}$ & $\begin{array}{l}\text { no } \\
0 / 10 / 0\end{array}$ \\
\hline 2 & corn & $\begin{array}{l}\text { MON810; } 0.01 \\
\text { NK603; } 0.01 \\
\text { MON863; } 0.01 \\
\text { TC1507; } 0.01 \\
\text { MON88017; } 0.01 \\
\text { DAS59122-7; } 0.01\end{array}$ & $\begin{array}{l}\text { yes } \\
8 / 1 / 1\end{array}$ & $\begin{array}{l}\text { yes } \\
7 / 1 / 2\end{array}$ & $\begin{array}{l}\text { yes } \\
7 / 2 / 1\end{array}$ & $\begin{array}{l}\text { no } \\
0 / 10 / 0\end{array}$ \\
\hline 3 & corn & $\begin{array}{l}\text { NK603; } 30 \\
\text { TC1507; } 78 \\
\text { MON89034; } 2.1\end{array}$ & $\begin{array}{l}\text { yes } \\
10 / 0 / 0\end{array}$ & $\begin{array}{l}\text { yes } \\
10 / 0 / 0\end{array}$ & $\begin{array}{l}\text { yes } \\
10 / 0 / 0\end{array}$ & $\begin{array}{l}\text { yes } \\
10 / 0 / 0\end{array}$ \\
\hline 4 & corn starch & $\begin{array}{l}\text { RRS; }>50 \\
\text { MON810; } 35 \\
\text { NK603; } 35 \\
\text { MON863; } 10 \\
\text { MON88017; } 11 \\
\text { DAS59122-7; >50 } \\
\text { MIR604; } 1.4\end{array}$ & $\begin{array}{l}\text { yes } \\
10 / 0 / 0\end{array}$ & $\begin{array}{l}\text { yes } \\
10 / 0 / 0\end{array}$ & $\begin{array}{l}\text { yes } \\
9 / 0 / 1\end{array}$ & $\begin{array}{l}\text { no } \\
0 / 9 / 1\end{array}$ \\
\hline 5 & corn/soy & $\begin{array}{l}\text { RRS; } 43 \\
\text { MON810; } 13 \\
\text { GA21; } 0.6 \\
\text { NK603; } 35 \\
\text { MIR604; } 7.7\end{array}$ & $\begin{array}{l}\text { yes } \\
10 / 0 / 0\end{array}$ & $\begin{array}{l}\text { yes } \\
10 / 0 / 0\end{array}$ & $\begin{array}{l}\text { no } \\
9 / 1 / 0\end{array}$ & $\begin{array}{l}\text { no } \\
10 / 0 / 0\end{array}$ \\
\hline 6 & soy & $\begin{array}{l}\text { RRS; } 75 \\
\text { MON89788; } 13\end{array}$ & $\begin{array}{l}\text { yes } \\
9 / 1 / 0\end{array}$ & $\begin{array}{l}\text { yes } \\
9 / 1 / 0\end{array}$ & $\begin{array}{l}\text { no } \\
7 / 3 / 0\end{array}$ & $\begin{array}{l}\text { yes } \\
9 / 1 / 0\end{array}$ \\
\hline 7 & soy & $\begin{array}{l}\text { RRS; } 60 \\
\text { A2704; } 0.2 \\
\text { MON89788; } 8.3\end{array}$ & $\begin{array}{l}\text { yes } \\
10 / 0 / 0\end{array}$ & $\begin{array}{l}\text { yes } \\
10 / 0 / 0\end{array}$ & $\begin{array}{l}\text { yes } \\
9 / 1 / 0\end{array}$ & $\begin{array}{l}\text { yes } \\
10 / 0 / 0\end{array}$ \\
\hline 8 & rice & $\begin{array}{l}\text { Bt63 } \\
\text { KeFeng6 }\end{array}$ & $\begin{array}{l}\text { yes } \\
9 / 1 / 0\end{array}$ & $\begin{array}{l}\text { yes } \\
10 / 0 / 0\end{array}$ & $\begin{array}{l}\text { yes } \\
9 / 1 / 0\end{array}$ & $\begin{array}{l}\text { no } \\
0 / 9 / 1\end{array}$ \\
\hline
\end{tabular}

and the template concentration used for the PCR runs. Other results, which look like false positive, showed probably mostly the presence of other GMO events which had not been detected by the first analysis by the food control lab, as for example the T-35S element in sample 6 or the T-35S and the P-FMV elements in sample 5.

\section{Conclusion}

The presented real-time PCR method is sensitive and specific for the detection of the four GMO screening elements P-35S, T-nos, T-35S and P-FMV in food and feed. The combination of these four screening elements could ensure a fast detection of the vast majority of all so far globally produced GMO events worldwide.

Received: July 1, 2014

[1] Swiss Food Manual, Chap. 52B, Method 2.1.7, Bern, 2000

[2] R. Reiting, H. Broll, H. U. Waiblinger, L. Grohmann, J. Verbr. Lebensm. 2007, 2, 116.

[3] M. Höhne, C. R. Santisi, R. Meyer, Eur. Food Res. Technol. 2002, 215, 59.

[4] H. U. Waiblinger, B. Ernst, A. Anderson, K. Pietsch, Eur. Food Res. Technol. 2008, 226, 1221.

[5] H. Zhang, L. Yang, J. Guo, X. Li, L. Jiang, D. Zhang, J. Agric. Food Chem. 2008, 56, 5514.

[6] T. Oguchi, M. Onishi, J. Mano, H. Akiyama, R. Teshima, S. Futo, S. Furui, K. Kitta, Shokuhin Eiseigaku Zasshi 2010, 51, 92.

[7] C. Bahrdt, A. B. Krech, A. Wurz, D. Wulff, Anal. Bioanal. Chem. 2010, 96, 2103.

[8] J. Pansiot, M. Chaouachi, L. Cavellini, M. Romaniuk, M. Ayadi, Y. Bertheau, V. Laval, Eur. Food Res. Technol. 2011, 232, 327.

[9] R. Köppel, F. van Velsen, N. Felderer, T. Bucher, Eur. Food Res. Technol. 2012, 235, 23.

[10] Swiss Food Manual, Chap. 52B, Method 1.1, Bern, 2004.

[11] T. Gaudron, C. Peters, E. Boland, A. Steinmetz, G. Moris, Eur. Food Res. Technol. 2009, 229, 295.

[12] Biolytix AG, Witterswil, Switzerland.

[13] http://www.cera-gmc.org/?action =gm_crop_ database
Table 5. List of the results from the participants of the proficiency test. The column 'GMO event [\%]' shows a short list of all the GMO events detected previous to the proficiency test. The concentration states the GMO content relative to the plant species in percent. The columns with the single screening elements show the expected analysis results (yes or no) and the number of the obtained summarized results from the participants positive/negative/not clear '+/-/nc'. 